\title{
PEMBELAJARAN KITAB KUNING PADA PONDOK PESANTREN KHUSUS AL-HALIMY DESA SESELA KABUPATEN LOMBOK BARAT
}

\author{
Ar Rasikh \\ Fakultas Ilmu Tarbiyah dan Keguruan UIN Mataram \\ e-mail: rosikhiain@gmail.com
}

\begin{abstract}
Abstrak: Kitab kuning merupakan faktor penting yang menjadi karakteristik Pondok Pesantren (Ponpes). Artikel ini membahas pembelajaran Kitab Kuning di Pondok Khusus Ponpes AlHalimy Sesela. Pembahasan difokuskan pada metode dan penerapannya dalam pembelajaran, serta teknik penilaian setelah pelakasanaan pembelajaran berlangsung. Hasil penelitian menunjukkan bahwa Pondok Khusus Al-Halimy Sesela menerapkan beberapa metode yang lazimnya digunakan di pondok-pondok Salaf, menggunakan metode klasik, yaitu metode sorogan, bandongan, wetonan, halaqoh, diskusi, demonstrasi, dan tanya jawab. Penerapan metode-metode dalam pembelajaran kitab kuning didasarkan kesesuaian metode yang akan digunakan dengan mata pelajaran yang akan diajarkan. Keberhasilan suatu metode yang diterapkan dalam pembelajaran kitab kuning di Pondok Khusus Al-Halimy Sesela diukur dengan menggunakan beberapa cara di antaranya adalah dengan menguji secara langsung. Hendaknya tradisi pesantren Salaf tetap dapat dipertahankan dan selanjutnya memasukkan tradisi pesantren khalaf yang lebih baik, pemilihan metode yang tepat guna supaya memberikan dampak positif bagi kemajuan pendidikan pesantren sehingga akan muncul lulusan-lulusan yang betul-betul tafaqquh fi al-din.
\end{abstract}

Kata Kunci: pembelajaran, Kitab Kuning, pondok pesantren

Title: Learning of Kitab Kuning "Yellow Book" at Special Al-Halimy Islamic Boarding School In Sesela Village of West Lombok Regency

Author: Ar Rasikh

Abstract: The yellow book is an important factor which becomes characteristic of Islamic Boarding Schools. The results of the preliminary research showed that the Special Al-Halimy Islamic Boarding School of Sesela only studies classical books or yellow books which are not included in the governmental curriculum. The focuses of the study in this research included: First, it is related to the method used in yellow book learning; Second, it is related to how the application of learning methods is; Third, it is related to how the assessment after the implementation of yellow book learning takes place. The research design used descriptive qualitative. Then the results of the research showed that 1) special Al-Halimy Islamic Boarding School of Sesela applies several methods commonly used in Salaf Islamic Boarding Schools which teach yellow books, such as sorogan (individual), wetonan (group), and discussion methods. In addition, the types of methods used still use classical methods, namely the sorogan, bandongan, wetonan, and halaqoh methods, and also there are discussion, demonstration and question and answer methods, 2). The application of methods in yellow book learning is based on the suitability of method to be used with the subjects to be tanght. 3). To find out the success level of a method applied in the yellow book learning at special Al-Halimy Islamic Boarding School of Sesela is by using several methods including testing directly. The final advice is given to the head of the Special Islamic Boarding School in order to maintain the tradition of the salaf Islamic Boarding School and incorporate the tradition of a better Khalaf Islamic Boarding School in order to give a positive impact on the progress of Islamic Boarding School education so that the graduates who truly understand the religion (tafaqquh $\mathrm{fi}$ al-din) will emerge and for the teachers of special Al-Halimy Islamic Boarding School of Sesela, they have to be able to choose the right learning method and be able to see what the students need in joining the learning so that the learning objectives can be achieved.

Keywords: learning, Kitab Kuning (Yellow books), Islamic boarding school. 


\section{Pendahuluan}

Pondok pesantren adalah salah satu lembaga yang menyelenggarakan pendidikan baik formal maupun non formal, yang memiliki peran strategis dalam membina, membentuk dan mencetak generasi bangsa yang mampu bersaing di era modern seperti sekarang ini. Pondok Pesantren merupakan salah satu lembaga pendidkan yang dapat digunakan sebagai wadah dalam pembaharuan dan peningkatan ilmu pengetahuan serta menciptakan peserta didik yang berakhlak mulia. Salah satu dari ciri utama pesantren yang membedakan dengan lembaga pendidikan yang lain adalah kitab kuning.

Dilihat dari sisi sejarah, pesantren telah memberikan andil dan kontribusi yang sangat besar dalam mencerdaskan kehidupan bangsa dan memberikan pencerahan terhadap masyarakat serta dapat menghasilkan komunitas intelektual yang setaraf dengan sekolah. Pada tataran ini "pesantren tidak hanya dapat diklaim sebagai institusi sosial yang berbentuk lembaga dengan seperangkat elemen pendukungnya seperti masjid, ruang mengaji, asrama santri dan beberapa guru dan kiai- tetapi juga merupakan entitas budaya yang mempunyai implikasi terhadap kehidupan sosial yang melingkupinya". ${ }^{1}$

Pembelajaran pada Pondok pesantren sangat identik dengan kitab-kitab klasik atau yang disebut juga dengan kitab kuning dan pengajarannya masih menggunakan sistem halaqoh. Halaqoh dari segi kebahasaan berarti "lingkarangan murid atau lingkaran belajar santri yaitu beberapa orang santri dengan jumlah tertentu membentuk halaqoh yang dipimpin langsung oleh seorang kiai atau ustaz atau juga santri senior untuk membahas atau mengkaji suatu persoalan yang telah ditentukan sebelumnya". ${ }^{2}$ Jadi, santri duduk bersila mengelilingi ustadz yang mengajar sambil mendengarkan pengajian yang disampaikan oleh ustadz tersebut.

Pada dasarnya kitab kuning mempunyai arti sebagai istilah yang diberikan kepada kitab yang berbahasa arab tanpa harokat dan arti yang biasanya menggunakan kertas berwarna kuning. Istilah kitab kuning muncul dilingkungan pondok pesantren yang ditunjukan kepada kitab-kitab ajaran islam yang ditulis dengan berbahasa arab tanpa harokat dan tanpa arti, kitab kuning ini sebagai standar bagi santri dalam memahami ajaran islam. Kitab kuning biasanya ditulis atau cetakan memakai huruf-huruf arab dalam Bahasa arab, melayu, jawa, dan sebagainya yang berasal sekitar abad XI hingga XVI masehi. ${ }^{3}$ Selanjutnya format kitab klasik yang paling umum dipakai di pesantren sedikit lebih kecil dari kertas kuarto $(26 \mathrm{~cm})$ dan tidak

1 Hamdan Farchan dan Syarifuddin, Titike Tengkar Pesantren: Resolusi Konflik Masyarakat Pesantren, (Yogyakarta: Pilar Religia, 2005), h. 1.

2 Samsul Nizar,. Sejarah Sosial \& Dinamika Intelektual Pendidikan Islam di Nusantara (Jakarta, Kencana Prenada Media group. 2013), h. 163.

3 Asep Usmani Ismail, Menguak yang Gaib Khasanah Kitab Kuning, (Jakarta: Penerbit Hikmah, 2002), h. 9. 
dijilid. Lembaran-lembaran (koras-koras) tak terjilid dibungkus kulit sampul, sehingga para santri dapat membawa hanya satu halaman yang sedang dipelajari saja. ${ }^{4}$

Kitab kuning merupakan faktor penting yang menjadi karakteristik Pondok Pesantren. Kitab kuning difungsikan oleh kalangan pesantren sebagai referensi yang kandunganya sudah tidak perlu dipertanyakan lagi. Kanyataanya kitab kuning yang ditulis sejak lama dan terus dipakai dari masa ke masa menunjukan bahwa kitab kuning sudah teruji kebenaranya dalam sejarah yang panjang. Kitab kuning merupakan kitab yang sudah sedemikian rupa dirumuskan oleh ulama-ulama dengan bersandar pada Al-Quran dan Hadits Nabi. ${ }^{5}$

Pembelajaran yang berkaitan dengan kitab kuning ataupun ilmu-ilmu agama merupakan suatu kesatuan dengan dunia pesantren sehingga setiap pesantren pastilah disitu ada pembelajaran mengenai kitab-kitab klasik yang sering disebut dengan kitab kuning. Meskipun kebanyakan pesantren telah memasukan pengajaran pengetahuan umum sebagai suatu bagian yang penting dalam pendidikan pesantren, namun kitab-kitab islam klasik tetap diberikan sebagai upaya untuk meneruskan tujuan utama pesantren yakni mendidik calon-calon generasi yang mempunyai pengetahuan agama, maupun umum yang luas, mendalam dan mutawatir hingga nantinya sampai sanadnya pada baginda Nabi Muhammad SAW.

Keseluruhan kitab-kitab klasik yang diajarkan di pesantren dapat digolongkan kedalam 8 kelompok: nahwu, sorof, fiqh, usul figh, hadits, tafsir, tauhid, tasawuf, dan cabang-cabang lain seperti tarikh dan balaghah. Kitab-kitab tersebut meliputi teks yang pendek sampai teks yang terdiri dari berjilid-jilid tebal yakni mengenai hadits, tafsir, fiqh, usul fiqh dan tasawuf.

Hasil studi pendahuluan menunjukkan bahwa Pondok Pesantren Khusus Al-Halimy Sesela hanya mempelajari kitab-kitab klasik atau kitab kuning yang tidak dimasukkan ke dalam kurikulum penerintah. Kitab-kitab kuning yang diajarkan di Pondok Pesantren Khusus Al-Halimy Sesela antaranya: bidang ilmu alat atau kawaid (nahwu, shorof) menggunakan kitab matan al-jurumiyah, syarb dablan, kafrawi, nabwu al-wadih, ibn 'aqil, mugni labib, 'Imriti (naz̧am), amtsilah al-jadidah, matan al-bina', dan kaylani. Selanjutnya keberhasilan proses belajar mengajar di pondok pesantren Al-Halimy Desa Sesela ini, tidak bisa dilepaskan dari kemampuan pengasuh maupun para ustadz dalam mengajar, ditambah kesesuaian materi yang diajarkan dan metode yang diterapkan dalam aktivitas belajar mengajar ilmu-ilmu keagamaan.

Berdasarkan latar belakang di atas, maka penulis merasa perlu untuk melakukan penelitian mengenai pembelajaran kitab kuning yang dilakukan di pondok pesantren khusus Al-Halimy. Untuk mempertegas dan memberikan batasan mengenai apa yang akan dikaji

${ }_{4}$ Martin Van Bruinnessen, Kitab Kuning, Pesantren dan Tarekat, Tradisi-Tradisi Islam di Indonesia, (Bandung: Penerbit Mizan, cet 1, 1995), h. 142.

5 Said Aqiel Siradj. Pesantren Masa Depan: Wacana Pemberdayaan dan Transformasi Pesantren, (Bandung: Pustaka Hidayah, 1999), h. 236. 
dalam penelitian ini maka penulis mengangkat tema "Pembelajaran Kitab Kuning Pada Pondok Pesantren Khusus Al-Halimy Desa Sesela Kabupaten Lombok Barat".

Berdasarkan pada konteks penelitian di atas maka penulis mencoba melakukan perenungan mendalam dalam rangka memastikan poin-poin penting persoalan pembelajaran kitab kuning pada pondok pesantren khusus al-Halimy yang dapat dikaji dalam jangka waktu yang relatif tidak lama dan memastikan permasalahan yang dikaji betul-betul memiliki urgensi dalam pengembangan khazanah keilmuan pada bidang pembelajaran kitab kuning. Untuk itu penulis merasa perlu melakukan identifikasi terhadap masalah yang akan dikaji secara holistik, sebagai berikut:

a. Berbicara tentang pembelajaran, lebih-lebih yang berlangsung pada pondok pesantren, maka kita akan berhadapan dengan beberapa komponen pembelajaran yang harus dikaji secara mendalam dan luas, hal ini memungkinkan didapatnya gambaran yang menyeluruh mengenai bagaimana pelaksanaan pembelajaran kitab kuning di pondok pesantren AlHalimy Desa Sesela Kab. Lombok Barat dan tentu saja membutuhkan waktu yang relatif lama jika ingin dikaji secara menyeluruh.

b. Pondok pesantren Al-Halimy Desa Sesela Kab. Lombok Barat sudah sejak lama melaksanakan kegiatan pembelajaran dengan ciri khas yakni lebih banyak muatan kitab klasik/kitab kuning daripada pelajaran umum, bahkan terkesan pelajaran-pelajaran umum dianak tirikan, atau sebagai formalitas untuk mendapatkan legalitas ijazah kelulusan dari satuan pendidikan saja, tentu saja hal ini menjadi keunikan tersendiri dan memiliki daya tarik yang cukup bagus untuk diteliti.

c. Pondok Pesantren Al-Halimy Desa Sesela Kab. Lombok Barat dikenal sebagai pencetak lulusan yang memiliki kemampuan yang mempuni pada bidang agama terutama pada penguasaan kitab-kitab kuning, hal ini terlihat dari struktur kurikulum yang ada, di mana banyak sekali kitab-kitab yang diajarkan kepada santri, di sini penulis sangat tertarik untuk melihat lebih dekat bagaimana pelaksanaan pembelajarannya dan kitab apa saja yang diajarkan.

d. Keberhasilan pelaksanaan pembelajaran kitab kuning di Pondok Pesantren Al-Halimy Desa Sesela Kab. Lombok Barat tidak terlepas dari diterapkannya berbagai metode mengajar, hal ini terlihat dari adanya keterpaduan antara penggunan metode konvensionl pesantren dan metode mengajar system persekolahan, terdapat persoalan yang menarik di sini, terutama bagaimana kolaborasi kedua jenis metode ini.

e. Sebagai bentuk tindak lanjut dari pelaksanaan pembelajaran kitab kuning dan dalam rangka mengetahui keberhasilan atau pencapaian belajar santri di Pondok Pesantren AlHalimy Desa Sesela Kab. Lombok Barat, maka kegiatan penilaian dan evaluasi sering sekali dilakukan, menjadi menarik jika cara-cara menilai kegiatan pembelajaran kitab kuning ini bisa di deskripsikan sehingga dapat menambah khazanah keilmuan. 
Mengkaji mengenai pembelajaran kitab kuning di Pondok Pesantren, tentu tidak cukup dengan penelitian ini saja, mengingat permasalahan yang terjadi sangat banyak dan sangat luas cakupan masalahnya, sehingga untuk menghindari melebarnya permasalahan tersebut, maka penulis membatasi masalah yang dikaji pada beberapa hal terkait pembelajaran kitab kuning, di antaranya: Pertama, terkait dengan metode yang digunakan dalam pembelajaran kitab kuning, Kedua. terkait dengan bagaimana penerapan metode-metode pembelajaran, Ketiga, terkait dengan bagaimana penilaian setelah pelakasanaan pembelajran kitab kuning berlangsung.

Terkait dengan penelitian yang akan dilakukan oleh penulis, berikut dirmuskan beberapa permasalahan yang dirasa sangat perlu untuk diteliti, di antaranya:

a. Metode apa saja yang digunakan dalam kegiatan pembelajaran kitab kuning di pondok pesantren Al-Halimy Desa Sesela Kab. Lombok Barat?

b. Bagaimanakah penerapan metode-metode pembelajaran kitab kuning di pondok pesantren Al-Halimy Desa Sesela Kab. Lombok Barat?

c. Bagaimanakah cara para asatidz melakukan kegiatan penilaian hasil belajar kitab kuning di pondok pesantren Al-Halimy Desa Sesela Kab. Lombok Barat?

\section{Pembahasan}

\section{Jenis-jenis metode yang digunakan dalam kegiatan pembelajaran kitab kuning di pondok pesantren Al-Halimy.}

Pondok pesantren dalam pelaksanaan pembelajaran kitab kuning, tidak terlepas dari penerapan metode baik yang bersifat konvensional maupun metode-metode yang bervariatif. Pelaksanaan pembelajaran kitab kuning di pondok pesantren lebih-lebih pondok salaf yang dalam hal ini Pondok Khusus Al-Halimy Sesela masih menyelenggarakan pembelajaran kitab kuning semenjak berdirinya sampai sekarang. Sebagai Pondok dengan ciri salaf, Pondok Khusus Al-Halimy Sesela menyelenggarakan pembelajaran kitab kuning untuk semua tingkatannya (MTs dan MA). Kitab-kitab yang dipelajari adalah kitab-kitab kuning (kitab gundul) yang merupakan salah satu ciri hkasnya.

Ahmad Barizi memaparkan bahwa, Pertama, kitab kuning adalah kitab yang di tulis oleh ulama klasik islam yang secara berkelanjutan dijadikan referensi yang dipedomani oleh para ulama Indonesia, seperti Tafsir Ibn Katsir, Tafsir al-Khazin, Shahih Bukhari, Shahih Muslim, dan sebagainya. Kedua, kitab kuning adalah kitab yang ditulis oleh ulama Indonesia sebagai karya tulis yang independen, seperti Imam Nawawi dengan kitabnya Mirah Labid dan Tafsir al-Munir. Ketiga, kitab kuning adalah kitab yang ditulis oleh ulama Indonesia sebagai komentar atau terjemahan atas kitab karya ulama asing, kitab-kitab Kyai Ihsan Jampes, yaitu Siraj al-Thalibin dan Manahij al-Imdad, yang masing-masing merupakan komentar atas Minhaj al-'Abidin dan Irsyad al-'Ibad karya Al Ghazali. 
Adapun cirri-ciri kitab kuning yaitu:

1) Kitab-kitabnya berbahasa Arab;

2) Umumnya tidak memakai syakal, bahkan tanpa titik dan koma;

3) Berisi keilmuan yang cukup berbobot;

4) Metode penulisannya dianggap kuno dan relevansinya dengan ilmu kontemporer kerap kali tampak menipis;

5) Lazimnya dikaji dan dipelajari di pondok pesantren;

6) Banyak diantara kertasnya berwarna kuning.

Melihat karakteristik dari kitab kuning yang lazimnya dipelajari maka sudah bisa dipastikah bahwa, kitab kuning merupakan salah satu khazanah klasik yang masih dipertahankan sampai sekarang. Selain itu, berkenaan dengan kitab-kitab kuning yang dipelajari di pondok pesantren salaf khususnya, di Pondok Khusus Al-Halimy Sesela juga melakukan hal yang sama. Di pondok ini ada beberapa kitab kuning yang dipelajari yang disesuaikan dengan tingkatan santri.

Kitab-kitab yang dipelajari di Pondok Khusus Al-Halimy Sesela adalah kitab Tafsir dan Ushul Tafsir, Hadits dan Musthalahul Hadits, Aqidah, Fiqih dan Ushul Fiqh, Nahwu Shorf, Tarikh, Faroid, Tajwid dan Bahasa Arab”. Semua kitab tersebut dipelajari di Pondok Khusus Al-Halimy Sesela sebagai mata pelajaran wajib bagi santri. Tetapi semua kitab tersebut disesuaikan dengan jenjang dan tingkatan santri. Upaya ini dilakukan agar santri mampu menyerap semua konten yang terkandung. Upaya lain yang dilakukan adalah dengan melihat dan mempertimbangkan karakteristik dari peserta didik. Bagian ini harus mendapat perhatian lebih karena merupakan salah satu faktor yang mampu menghambat atau pun sebaliknya.

Pendekatan yang digunakan di Pondok Khusus Al-Halimy Sesela adalah dengan pendekatan yang berbeda-beda tergantung mata pelajarannya, pada mata pelajaran ilmu Nahwu dan Shorf maka pendekatan yang digunakan adalah dengan cara memaparkan contoh-contoh terlebih dahulu baru kemudian dijelaskan materinya, dan begitu pula sebaliknya, materi dulu yang disampaikan baru kemudian didatangkan contoh-contohnya, juga dengan cara membuat kelompok-kelompok belajar.

Pendekatan yang digunakan di Pondok Khusus Al-Halimy Sesela bisa dikatakan sebagai pendekatan yang lebih berpusat pada siswa. Siswa tidak lagi diposisikan sebagai objek belajar tetapi sebagai subjek belajar. Berkenaan dengan hal ini Muzayyin, mengemukakan bahwa, dalam Pendidikan Agama Islam harus memperhatikan beberapa aspek yaitu:

1) Pendidik dengan metodenya harus mampu membimbing, mengarahkan, dan membina anak didik menjadi manusia yang matang atau dewasa dalam sikap dan kepribadiannya, sehingga terambarlah dalam tingkah lakunya nilai-nilai Islam dalam dirinya. 
2) Anak didik yang tidak hanya menjadi objek pendidikan atau pengajaran, melaikan juga menjadi subyek yang belajar, memerlukan suatu metode belajar agar dalam proses belajarnya dapat searah dengan cita-cita pendidik atau pengajarnya.

Dengan demikian diharuskan bagi setiap guru untuk lebih memahami pendekatan yang digunakan. Fungsi lainnya adalah agar metode yang diterapkan bisa berjalan dengan baik. Karena apabila metode yang ditetapkan bisa berjalan dengan baik dimungkinkan tujuan bisa dicapai dengan baik pula. Metode dengan segala variasinya sangat membantu guru dalam proses pembelajaran terlebih lagi pembelajaran kitab kuning. Pola dan kondisi belajar makin terbangun dengan menggunakan metode-metode yang bervariasi. Karena setiap materi tidak bisa diseragamkan dengan hanya menggunakan satu metode saja. Di sisi lain siswa juga akan jenuh dengan gaya mengajar guru yang hanya monoton dalam menggunakan metode.

Pondok Khusus Al-Halimy Sesela menerapkan beberapa metode yang lazimnya digunakan di pondok-pondok salaf yang mengajarkan kitab kuning, seperti, metode sorogan, bandongan, wetonan, dan diskusi. Selain itu jenis metode yang digunakan masih menggunakan metode klasik yaitu metode sorogan, bandongan, wetonan, dan halaqoh, dan ada juga metode diskusi, demonstrasi, dan ada juga metode tanya jawab.

Pada prinsipnya, semakin banyak metode yang digunakan maka tingkat ketercapaian materi yang diajarkan juga akan semakin baik. Menurut Zamakhsyari Dhofier dan Nurclolish Madjid dalam Said Aqil Siradj, "metode pembelajaran kitab kuning meliputi, metode sorogan dan bandongan, sedangkan Husein Muhammad menambahkan bahwa, selain metode wetonan atau bandongan, dan metode sorogan, diterapkan juga metode diskusi (munadzarah), metode evaluasi, dan metode hafalan".

Dengan demikian dapat dikatakan bahwa, semakin banyak metode yang digunakan maka semakin baik pula pola dan intensitas pembelajaran yang berlangsung, sehingga guru semakin kreatif dalam membangun komunikasi yang bersifat edukatif, dan tidak hnya komunikasi satu arah tetapi multi arah. Guru juga tidak bisa memaksakan diri untuk mengajar secara monoton dengan hanya menggunakan satu jenis metode saja.

Implikasi yang ditimbulkan adalah kejenuhan dari siswa dan mengakibatkan kurangnya gairah belajar siswa. Apalagi konten atau materi yang terkandung dari kitab kuning memiliki tingkat kesulitan-yang tidak bisa diremehkan oleh guru. Hal lain yang harus diwaspadai adalah kurangnya minat, motivasi dan gairah dari siswa yang hanya mengikuti proses pembelajaran tanpa ikut serta dalam setiap kegiatan pembelajaran. Metode-metode yang dikembangkan bukan hanya menggunakan metode konvensional, tetapi juga harus menggunakan metode yang bervariasi agar komunikasi yang di bangun lebih kondusif.

Terkait dengan hal di atas, di Pondok Khusus Al-Halimy Sesela dalam pembelajaran kitab kuning lebih mengedepankan meode-metode klasik seperti metode sorogan, 
bandongan, wetonan, dan halaqoh yang memang merupakan ciri khas pesantren salaf. Ada juga metode lain seperti metode diskusi, tanya jawab, dan hafalan serta demonstrasi.

Dari hal ini dapat diketahui bahwa, proses pembelajaran "klasik" masih dipegang teguh di Pondok Khusus Al-Halimy Sesela ini. Belum banyak inovasi-inovasi yang dilakukan dari para pengajar. Prinsip seperti ini akan menimbulkan suasana yang monoton dan mendatangkan kejenuhan siswa ketika mengikuti pembelajaran.

Mengutip pendapatnya Pupuh dan sobry menjelaskan bahwa, "penggunaan metode yang tidak sesuai dengan tujuan pengajaran akan menjadi kendala dalam pencapaian tujuan yang telah dirumuskan. Cukup banyak bahan pelajaran yang terbuang dengan percuma hanya karena penggunaan metode semata-mata berdasarkan kehendak guru dan bukan atas dasar kebutuhan siswa, atau karakter situasi kelas".

Paradigma guru yang salah terhadap pola pembelajaran yang nantinya akan berdampak pada kurangnya minat siswa terhadap materi yang disampaikan alih-alih mendapat respon yang negatif dari siswa. Dalam hal ini guru tidak peka terhadap kebutuhan siswa, minat, bakat, karakteristik dan gaya belajarnya. Bisa dipastikan, tujuan yang seharusnya bisa dicapai dengan maksimal, terhambat karena kurang cerdasnya guru dalam memahami permasalahan tersebut.

\section{Penerapan Metode-Metode Pembelajaran Kitab Kuning di Pondok Pesantren Al- Halimy.}

Guru sebagai salah satu sumber belajar berkewajiban menyediakan lingkungan belajar yang kreatif bagi kegiatan belajar anak didik di kelas. Salah satu kegiatan yang harus dilakukan adalah melakukan penentuan dan pemilihan metode. Suatu metode yang digunakan oleh guru untuk mengajar harus benar-benar dikuasai. Sehingga pada saat penggunaannya dapat menciptakan suasana interaksi edukatif.

Untuk menghindari kejenuhan dan berhentinya minat siswa terhadap pelajaran yang disampaikan maka hendaknya guru menggunakan metode yang bervariasi. Bahkan metode yang digunakan dapat menumbuhkan keinginan siswa untuk belajar secara mandiri dengan menggunakan teknik tersendiri. Di dalam kelas guru menyampaikan bahan pelajaran. Bahan pelajaran itu akan kurang memberikan dorongan kepada siswa untuk belajar lebih lanjut bila penyampaiannya menggunakan strategi yang kurang tepat. Metode-metode yang dipilih dipergunakan berdasarkan manfaatnya, jadi seorang guru dikatakan kompeten bila ia memiliki khazanah cara penyampaian yang kaya dan memiliki kriteria yang akan digunakan untuk memilih cara-cara dalam menyajikan pengalaman belajar mengajar. Dalam proses belajar mengajar juga dibutuhkan alat bantu yang digunakan untuk menghilangkan verbalitas. Sehingga siswa lebih cepat menyerap materi yang telah disampaikan. 
Metode pembelajaran yang diterapkan guru hendaknya dapat mewujudkan hasil karya siswa. Siswa dituntun untuk dapat berfikir kritis dan kreatif dengan memberikan kesempatan kepada siswa untuk menyampaikan ide-idenya. Pemilihan metode yang kurang tepat dengan sifat bahan dan tujuan pembelajaran menyebabkan kelas kurang bergairah dan kondisi siswa kurang kreatif. Sehingga dengan penerapan metode yang tepat dengan berbagai macam indikator tersebut dapat meningkatkan minat siswa pada bahan pelajaran yang disampaikan dan minat yang besar pada akhirnya akan berpengaruh terhadap prestasi yang akan diraihnya.

Terkait dengan penerapan metode pada kegiatan pembelajaran kitab kuning di Pondok Pesantren Al-Halimy, para asatidz terlebih dahulu menyesuaikan metode yang akan digunakan dengan mata pelajaran yang akan diajarkan. Hal tersebut sesuai dengan kriteria pemilihan metode pembelajaran, yakni harus sesuai dengan sifat dan tujuan materi pelajaran.

\section{Cara Para Asatidz Melakukan Kegiatan Penilaian Hasil Belajar Kitab Kuning di Pondok Pesantren Al-Halimy.}

Metode mempunyai andil yang cukup besar dalam kegiatan belajar mengajar. Kemampuan yang diharapkan dapat dimiliki anak didik, akan ditentukan oleh kerelevansian penggunaan suatu metode yang sesuai dengan tujuan. Itu berarti tujuan pembelajaran akan dapat dicapai dengan penggunaan metode yang tepat sesuai dengan standar keberhasilan yang terpatri di dalam suatu tujuan. Metode yang dapat dipergunakan dalam kegiatan belajar mengajar bermacam-macam. Penggunaannya tergantung dari rumusan tujuan. Dengan bergairahnya belajar anak didik tidak sukar untuk mencapai tujuan pengajaran. Karena bukan guru yang memaksakan anak didik untuk mencapai tujuan, tetapi anak didiklah dengan sadar untuk mencapai tujuan.

Berkaitan dengan hal tersebut di atas Pondok Khusus Al-Halimy Sesela, ukuran yang digunakan untuk mengetahui tingkat ketercpaian suatu metode adalah dengan menguji secara langsung yaitu dengan cara menyuruh siswa membaca kitab kuning satu-persatu sebelum memulai pelajaran, atau dengan cara menunjuk siswa yang dianggap belum bisa untuk membaca kitab kuning dengan menilai kelancaran bacaannya, dan ketepatan harokatnya supaya siswa bisa mengetahui di mana tempat kekurangannya, dengan cara seperti itu siswa akan memperhatikan bacaan yang dibacakan oleh ustadz ketika belajar dan siswa akan mempersiapkan diri dengan cara membaca dan berdiskusi dengan sesama temannya tentang harokat yang tepat untuk mengantisifasi kalau-kalau siswa disuruh baca oleh ustadznya sebelum memulai pembelajaran.

Cara lain yang digunakan adalah dengan cara uji publik yaitu dengan cara mengadakan diskusi kelompok dan menyuruh siswa membacakan isi kitab kuning dan menterjemahkan serta menjelaskan maksud dari isi kitab tersebut di hadapan para audien atau teman-temannya yang lain dan didampingi atau diawasi oleh ustadz nanti di sana akan ketahuan mana yang 
sudah paham dan mana yang belum. Dengan cara seperti ini siswa akan mendapatkan pengalaman bagaimana cara menyampaikan materi di depan umum dan bagaimana cara menjawab pertanyaan atau persoalan secara langsung, karena hal semacam ini juga akan ditemukan esok di masyarakat kalau mereka sudah keluar dari Pondok.

Dari pemaparan di atas dapat diketahui bahwa, ukuran yang digunakan di Pondok Khusus Al-Halimy Sesela untuk mengetahui tingkat keberhasilan suatu metode adalah dengan melihat secara langsung aktivitas edukatif yang dilakukan oleh santri, ini sangat baik karena akan memudahkan guru dalam melihat dan menilai tingkat keberhasilan dari penerapan metode secara langsung. Menurut hemat peneliti, standar keberhasilan suatu metode bisa dilihat dengan tercapainya tujuan pembelajaran secara mikro, dan memungkinkan akan mengarah pada tercapainya tujuan pembelajaran secara makro.

Hal lain yang juga mempengaruhi adalah ketepatan guru dalam memilih metode yang digunakan dalam proses pembelajaran kitab kuning. "Secara umum ada beberapa hal yang menjadi perhatian guru dalam memilih metode yaitu:

1) tujuan yang hendak dicapai atau kompetensi yang harus dikuasai peserta didik;

2) peserta didik;

3) bahan pelajaran;

4) fasilitas;

5) situasi;

6) parsitipasi;

7) pendidik; dan

8) kebaikan dan kelemahan metode tertentu".

Pendapat di atas melihat metode secara komplek dari semua unsur yang terkait, sehingga kecil kemungkinan terjadinya kesalahan ketika diterapkan dalam proses pembelajaran. Dalam hal ini, di Pondok Khusus Al-Halimy Sesela pemilihan metode bergantung pada materi yang akan dipelajari. Dengan cara seperti ini akan memudahkan guru dalam menyampaiakan materi atau bahan ajar. Dalam hal ini guru harus peka dalam melihat kondisi kelas dan kondisi santri sehingga pemilihan metode juga tepat, jangan sampai salah dalam memilih metode maka ini akan menyulitkan siswa dalam mengikuti pelajaran karena belum tentu metode yang digunakan bisa diseragamkan untuk semua siswa dengan karakter dan gaya belajarnya yang berbeda-beda. Untuk mengantisipasi hal tersebut sudah sewajarnya guru membuat beberapa inovasi dalam menggunakan metode ketika proses pembelajaran berlangsung. Karena idealnya penggunaan metode akan menghasilkan kemampuan yang sesuai dengan karakteristik metode tersebut. Kemampuan yang dihasilkan oleh metode ceramah akan berbeda dengan kemampuan yang dihasilkan oleh metode diskusi. Salah satu inovasi tersebut adalah dengan menggunakan metode mengajar yang berfariasi 
(menggabungkan beberapa metode). Penggunaan metode mengajar yang berfariasi dapat menggairahkan belajar anak didik.

Kaitannya dengan hal tersebut, di Pondok Khusus Al-Halimy Sesela ketika proses pembelajaran kitab kuning, guru biasanya menggabungkan beberapa metode agar memudahkan siswa belajar. Misalnya saja, ketika proses pembelajaran fiqih, guru menggabungkan metode yaitu metode diskusi dan tanya jawab. Kegiatan ini dilakukan agar siswa tidak hanya paham dengan materi saja tetapi mengalami secara langsung.

Hal tersebut dilakukan karena beberapa hal yaitu:

1) Agar materi dipahami dengan baik oleh semua santri;

2) Memudahkan guru dalam menyampaikan materi ajar;

3) Tidak terjadi pengulangan materi karena masih banyak santri yang tidak paham dengan materi yang diajarkan.

Dengan demikian dapat diketahui bahwa, pada dasarnya penggunaan metode yang bervariasi akan memudahkan guru dalam membangun komunikasi edukatif di satu sisi, dan di sisi lain siswa akan lebih bersemangat dalam belajar karena siswa merasa terpenuhi modalitas dan gaya belajarnya, sehingga tidak ada kejenuhan dalam belajar.

\section{Penutup}

Berdasarkan hasil penelitian dan pembahasan dalam tesis ini yang berjudul "Metode Pembelajaran Kitab Kuning di Pondok Pesantren Khusus Al-halimy Sesela" dapat disimpulkan bahwa:

1. Pondok Khusus Al-Halimy Sesela menerapkan beberapa metode yang lazimnya digunakan di pondok-pondok salaf yang mengajarkan kitab kuning, seperti, metode sorogan, wetonan, dan diskusi. Selain itu jenis metode yang digunakan masih menggunakan metode klasik yaitu metode sorogan, bandongan, wetonan, dan halaqoh, dan ada juga metode diskusi, demonstrasi, dan ada juga metode tanya jawab.

2. Penerapan metode-metode dalam pembelajaran kitab kuning didasarkan kesesuaian metode yang akan digunakan dengan mata pelajaran yang akan diajarkan.

3. Untuk mengetahui tingkat keberhasilan suatu metode yang diterapkan dalam pembelajaran kitab kuning di Pondok Khusus Al-Halimy sesela adalah dengan menggunakan beberapa cara di antaranya adalah dengan menguji secara langsung yaitu dengan cara menyuruh siswa membaca kitab kuning satu-persatu sebelum memulai pelajaran, atau dengan cara menunjuk siswa yang dianggap belum bisa untuk membaca kitab kuning dengan menilai kelancaran bacaannya, dan ketepatan harokatnya supaya siswa bisa mengetahui di mana tempat kekurangannya, dengan cara seperti itu siswa akan memperhatikanbacaan yang dibacakan oleh ustadz ketika belajar dan siswa akan mempersiapkan diri dengan cara membaca dan berdiskusi dengan sesama temannya 
tentang harokat yang tepat untuk mengantisifasi kalau-kalau siswa disuruh baca oleh ustadznya sebelum memulai pembelajaran.

Selanjutnya berdasarkan temuan penelitian yang peneliti peroleh, maka bebrapa saran dapat peneliti kemukakan berkaitan dengan pelksanaan pembelajran kitab kuning di Pondok Khusus Al-Halimy, di antaranya:

1. Pimpinan pondok pesantren

Pimpinan Pondok Khusus Al-Halimy Sesela diharapkan agar dapat mempertahankan tradisi pesantren salaf dan memasukkan tradisi pesantren khalaf yang lebih baik guna memberikan dampak positif bagi kemajuan pendidikan pesantren sehingga akan muncul lulusan-lulusan yang betul-betul tafaqquh fi al-din.

2. Guru/ Ustadz

Kepada guru Pondok Khusus Al-Halimy Sesela agar mampu memilih metode pembelajaran yang tepat dan bisa melihat apa yang dibutuhkan santri dalam mengikuti pembelajaran agar tujuan pembelajaran bisa tercapai.

\section{Daftar Pustaka}

Afifuddin, Beni Ahmad Saebani. Metodologi Penelitian Kualitatif. Bandung, Pustaka Setia, 2009. Ahlan, "Metode Pembelajaran dalam Memahami Isi Kitab Kuning di Ma'had 'Aly Pondok Pesantren Nurul Hakim Kecamatan Kediri Lombok Barat tahun 2015.” Tesis, 2015.

Anhari, Masjkur. Integrasi Sekolah Ke dalam Sistem Pendidikan Pesantren (Surabaya: Diantama, 2007.

Arief, Armai. Pengantar Ilmu dan Metodologi Pendidikan Islam. Jakarta: Ciputat Press, 2002.

Arifin, M. Kapita Selekta Pendidikan Islam dan Umum. Jakarta : Bumi Aksara, 1991.

Arifin, Muzayyin. Filsafat Pendidikan Islam. Jakarta: Bumi Aksara, 2009.

Arikunto, Suharsimi. Prosedur Penelitian Suatu Pendekatan Praktik. Jakarta: Rineka Cipta, 2010.

Athiyah, Muhammad. Al-Tarbiyah wa Falasifuha. Mesir: Al-Nalaby, 1969.

Azra. Azyumardi, Pendidikan Islam: Tradisi dan Modernisasi Menuju Milenium Baru. Jakarta: Logos Wacana Imu, 1999.

Azra. Azyumardi, "Pesantren Kontinuitas dan Perubahan" dalam Nurcholis Majid, Bilik-bilik Pesantren. Jakarta : Paramadina, 1997.

Barizi, Ahmad. Pendidikan Intregratif: Akar Tradisi \& Intregasi Keilmuan Pendidikan Islam. Malang: UIN Maliki Press, 2011.

Bungin, M. Burhan. Penelitian Kualitatif: Komunikasi, Ekonomi, Kebijakan Publik, dan Ilmu Sosial Lainnya. Jakarta: Kencana Prenada Media Group, 2007.

Departemen Agama R.I. Metodologi Pendidikan Agama Islam. Jakarta: Direktorat Jenderal Kelembagaan Agama Islam, 2002. 
Dhofier, Zamakhsyari. Tradisi Pesantren Studi tentang Pandangan Hidup. Jakarta: LP3ES, 1985.

Djmarah, Syaiful Bahri dan Aswan Zain. Strategi Belajar Mengajar. Jakarta: Rineka Cipta, 2014.

Emzir. Metodologi Penelitian Kualitatif: Analisis Data. Jakarta: Raja Grafindo Persada, 2012.

Farchan, Hamdan dan Syarifuddin. Titik Tengkar Pesantren: Resolusi Konflik Masyarakat Pesantren. Yogyakarta: Pilar Religia, 2005.

Fathurrahman, Pupuh dan M. Sobry Sutikno. Strategi Belajar Mengajar Melalui Penanaman Konsep Umum \& Konsep Islami. Bandung: Refika Aditama, 2014.

Hadi, Sutrisno. "Deresan dalam Metode Bandongan sebuah Studi tentang Pembelajaran Kitab Kuning di Pondok Pesantren Karangasem Pacitan Lamongan.” Disertasi, 2008.

Hamdani. Strategi Belajar Mengajar. Bandung: Pustaka Setia, 2011.

Hielmy, Irfan. Pesan Moral dari Pesantren: Menigkatkan Kualitas Umat, Menjaga Ukhuwah. Bandung: Nuansa, 1999.

Mahfudh, Sahal. Nuansa Fiqih Sosial. Yogyakarta: LKiS, 1994.

Majid, Nurcholis. Bilik-bilik Pesantren. Jakarta: Paramadina, 1997.

Makmun, Abin Syamsudin. Psikologi Kependidikan Perangkat Sistem Pengajaran Modul. Bandung: Remaja Rosdakarya Offset, 2009.

Margono, Metodologi Penelitian Pendidikan. Jakarta: Rineka Cipta, 2005.

Misrawi, Zuhairi. Hadratussyaikh Hasyim Asy'ari Moderasi, Keumatan, dan Kebangsaan. Jakarta: Kompas, 2010.

Moleong, Lexy J. Metodologi Penelitian Kualitatif. Bandung: Remaja Rosdakarya, 2012.

Muhaimin dan Abdul Mujib. Pemikiran Pendidikan Islam: Kajian Filosofis dan Kerangka Dasar Operasionalnya. Bandung: Trigenda karya, 1993.

Mulkhan, Abdul Munir. Runtubnya Mitos Politik Santri, Strategi Kebudayaan dalam Islam. Yogyakarta: Sipress, 1994.

Mulyono Abdurrahman, Pendidikan Bagi Anak Berkesulitan Belajar. Jakarta: Rineka Cipta, 1998)

Mundir, Sudikin. Metode Penelitian Membimbing dan Mengantar Kesuksesan Anda dalam Dunia Penelitian. Surabaya: Insane Cendekia, 2005.

Nasution, S. Berbagai Pendekatan dalam Proses Belajar \& Mengajar. Jakarta: Bumi Aksara. 2010.

Nizar, Samsul. Sejarah Sosial \& Dinamika Intelektual Pendidikan Islam di Nusantara. Jakarta: Kencana Prenada Media Group, 2013.

Purwanto, Ngalim. Ilmu Pendidikan Teoretis dan Praktis. Bandung: Remaja Rosdakarya Offset, 2007.

Qomar, Mujamil. Pesantren dari Transformasi Metodologi Menuju Demokrasi Institusi. Jakarta: Erlangga, 1996.

Ramayulis, Metodologi Pendidikan Agama Islam. jakarta: Kalam Mulia, 2008. 
Saleh, Abdurrahman. Pedoman Pembinan Pondok Pesantren. Jakarta: Departemen Agama RI, 1982.

Siradj, Said Aqil. Pesantren Masa Depan. Cirebon. Pustaka: Hidayah, 2004.

Steenbrink, Karel A. Pesantren, Madrasah, Sekolab: Pendidikan Islam Dalam Kurun Modern. Jakarta, LP3ES, 1986.

Sugihartiono, dkk. Psikologi Pendidikan. Yogyakarta: UNY Press, 2007.

Sugiyono. Metode Penelitian Pendidikan (Pendekatan Kualitatif, Kuantitatif, dan R\&D). Bandung: Alfabeta, 2010.

Sujdana, Nana dan Ibrahim. Penelitian dan Penilaian Pendidikan. Bandung: Sinar Baru Algensindo, 2001.

Sukardi. Evaluasi Pendidikan Prinsip \& Operasionalnya. Jakarta: Bumi Aksara, 2010.

Syah, Muhibbin. Psikologi Belajar. Jakarta: Raja Grafindo Persada, 2013.

Tadjab, Ilmu Jiwa Pendidikan. Surabaya: Karya Abditama, 1994.

Tambak, Syahrani. 6 Metode Komunikatif Pendidikan Agama Islam. Yogyakarta: Graha Ilmu. 2014.

Turmudi, Endang. Perseligkuban Kyai dan Kekuasaan. Yogyakarta: Lkis, 2004.

van Bruinessen, Martin. Kitab Kuning: Pesantren dan Tarekat. Bandung: Mizan, 1995.

Wahid, Abdurrahman. Pesantren Masa Depan. Bandung: Pustaka Hidayah, 1999.

Widodo, Sembodo Ardi. "Pendidikan Islam Pesantren Studi Komparatif Struktur Keilmuan Kitab-kitab Kuning dan Implementasinya di Pondok Pesantren Tebu Ireng Jombang dan Mu'allimin Muhammadiyah Yogyakarta.” Disertasi, 2005. 